\title{
Kasus Serial : Aspirasi Peluit pada Anak
}

\author{
Aci Mayang Sari, Fachzi Fitri, Novialdi
}

\begin{abstract}
Abstrak
Kasus aspirasi benda asing selalu memberikan tantangan bagi dokter spesialis Telinga Hidung Tenggorok Kepala dan Leher (THT-KL). Aspirasi benda asing lebih sering terjadi pada anak-anak khususnya pada umur 1-3 tahun dan jarang terjadi pada dewasa. Aspirasi peluit pada anak merupakan kasus yang banyak terjadi pada golongan benda asing anorganik. Untuk menegakkan diagnosis aspirasi benda asing diperlukan ketajaman anamnesis, pemeriksaan fisik dan hasil radiografi. Bronkoskopi merupakan teknik yang digunakan sebagai alat diagnostik dan terapeutik pada kasus aspirasi benda asing. Kasus aspirasi peluit pada tiga orang anak (2 laki-laki dan 1 perempuan) telah dilaporkan dan ditatalaksana menggunakan teknik bronkoskopi kaku.
\end{abstract}

Kata kunci: Aspirasi benda asing, benda asing peluit, bronkoskopi

\begin{abstract}
Foreign body aspiration continues to provide challenges for otorhinolaryngologists. Foreign body aspiration is more common in children, especially at the age of 1-3 years and rarely occurs in adults. Whistle aspiration in children is a case that occurs in many inorganic foreign body type. The diagnosis of foreign body aspiration based on discernment anamnesis, physical examination and radiographic results. Bronchoscopy is a technique that is used as a diagnostic and therapeutic tool in cases of foreign body aspiration.Cases of whistle aspiration in 3 children (2 males and 1 female)was reported and treated using rigid bronchoscopy technique. Arial 9 italic
\end{abstract} Keywords: foreign body aspiration, a whistle foreign body, bronchoscopy.

Affiliasi penulis : Bagian Telinga Hidung Tenggorok Bedah Kepala dan Leher Fakultas Kedokteran Universitas Andalas/RS Dr.M.Djamil Padang

Korespondensi : Aci Mayang Sari, E-mail: achiems85@gmail.com, Telp: 081363198555

\section{PENDAHULUAN}

Aspirasi benda asing merupakan suatu keadaan darurat dan memiliki pengaruh besar terhadap mortalitas dan morbiditas pada anak-anak meskipun teknik anastesi dan endoskopi sudah berkembang dengan baik. ${ }^{1-4}$

Benda asing di traktus trakeobronkial terjadi sebagian besar pada anak umur 1-3 tahun. ${ }^{1-3-5-7}$ Perbandingan antara laki-laki dan perempuan yaitu 2:1 dan benda asing yang paling banyak teraspirasi adalah kacang dan benda plastik (peluit). ${ }^{1,3}$ Angka kejadian aspirasi benda asing peluit di bagian THT-KL fakultas kedokteran Universitas Andalas/Dr.M.Djamil Padang periode Juli 2009-Desember 2011 sebanyak 7 orang.

Trakea merupakan pipa yang terdiri dar tulang rawan dan otot yang dilapisi oleh epitel torak berlapis semu bersilia mulai dari kartilago krikoid sampai percabangan bronkus kanan dan bronkus kiri. Panjang trakea kira-kira $12 \mathrm{~cm}$ pada pria dan $10 \mathrm{~cm}$ pada wanita. Diameter anterior posterior $13 \mathrm{~mm}$ dan diameter transversal $18 \mathrm{~mm}$. Cincin trakea meluas ke inferior dan posterior di antara bronkus kanan dan kiri membentuk sekat yang lancip yang disebut karina trakea bercabang menjadi bronkus utama kanan dan kiri. Lumen bronkus kanan seperempat kali lebih luas dari lumen bronkus kiri dan membentuk sudut 25 derajat ke lateral dari garis tengah sedangkan pada bronkus kiri membentuk sudut 45 derajat ke lateral dari garis tengah. ${ }^{8}$

Pada paru kanan terdapat tiga lobus yaitu lobus superior, media dan inferior. Paru kiri terdapat dua lobus yaitu lobus superior dan inferior. Setiap lobus memiliki bronkus sekunder atau bronkus lobaris (Gambar 1). ${ }^{8}$

Diagnosis aspirasi benda asing dapat ditegakkan dengan anamnesis, pemeriksaan fisik dan pemeriksaan penunjang. Penatalaksanaan aspirasi benda asing ini dengan pendekatan medikamentosa dan terapi bedah. ${ }^{6}$

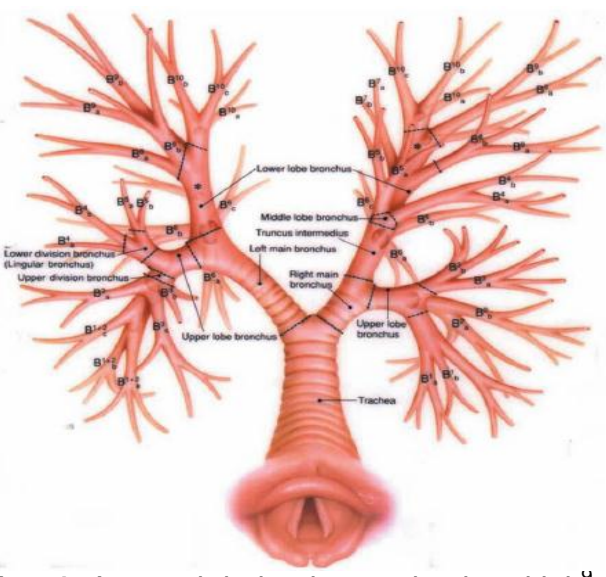

Gambar 1. Anatomi dari traktus trakeobronkial. $^{y}$

\section{Laporan Kasus \\ Kasus 1}

Seorang anak perempuan berumur 7 tahun berobat ke Instalasi Gawat Darurat (IGD) RSUP Dr. M. Djamil Padang pada tanggal 7 Oktober 2011 dengan keluhan tersedak peluit sejak 19 jam sebelum masuk rumah sakit. Sebelumnya pasien sedang bermain di tepi jalan sambil meniup peluit, tiba-tiba sepeda motor lewat dengan kencang dan akhirnya pasien terkejut dan tersedak. Pasien batuk setelah kejadian dan setiap pasien menghirup nafas terdengar suara seperti 
tiupan peluit. Tidak ada riwayat sesak nafas, suara serak dan kebiruan pada bibir dan jari. Tidak ada mual dan muntah serta air liur tergenang di mulut. Pasien masih bisa makan dan minum seperti biasa. Tidak ada riwayat nyeri menelan, hidung tersumbat serta keluar cairan di telinga.

Pada pemeriksaan fisik status generalis keadaan umum sedang, kesadaran composmentis kooperatif, nadi $64 \mathrm{kali} / \mathrm{menit}$, nafas $20 \mathrm{kali} / \mathrm{menit}$, suhu $36,6^{\circ} \mathrm{C}$,berat badan $20 \mathrm{~kg}$. Pada pemeriksaan regio toraks pada inspeksi tidak ditemukan retraksi suprasternal, interkostal dan epigastrium, toraks simetris kiri dan kanan, pada palpasi fremitus paru kiri sama dengan paru kanan, perkusi sonor dan auskultasi vesikuler, tidak ada ronki, wheezing, stridor, suara paru kanan melemah dari paru kiri. Jantung dalam batas normal.

Pada pemeriksaan status lokalis THT-KL, telinga, hidung dan tenggorok dalam batas normal. Pemeriksaan laringoskop tidak langsung dalam batas normal dan tidak ditemukan peluit.

Hasil laboratorium darah didapatkan hemoglobin $(\mathrm{Hb}) \quad 13,1 \mathrm{~g} / \mathrm{dl}$, leukosit $10.600 / \mathrm{mm}^{3}$, hematokrit $39,4 \%$, trombosit $339.000 / \mathrm{mm}^{3}$, APTT 33,5 detik, PT 12,5 detik, Natrium (Na) $141 \mathrm{mmol} / \mathrm{L}$, Klorida (Cl) $108 \mathrm{mmol} / \mathrm{L}$, Kalium (K) $4,0 \mathrm{mmol} / \mathrm{L}$ dan gula darah sewaktu (GDS) $90 \mathrm{mg} / \mathrm{dl}$.

Pada tanggal 7 Oktober 2011 dilakukan pemeriksaan rontgen Servikotorakal posisi anteroposterior (AP) dan servikotorakal posisi lateral soft tissue setting, dan didapatkan hasil tidak tampak benda asing di saluran nafas (Gambar 2,3)

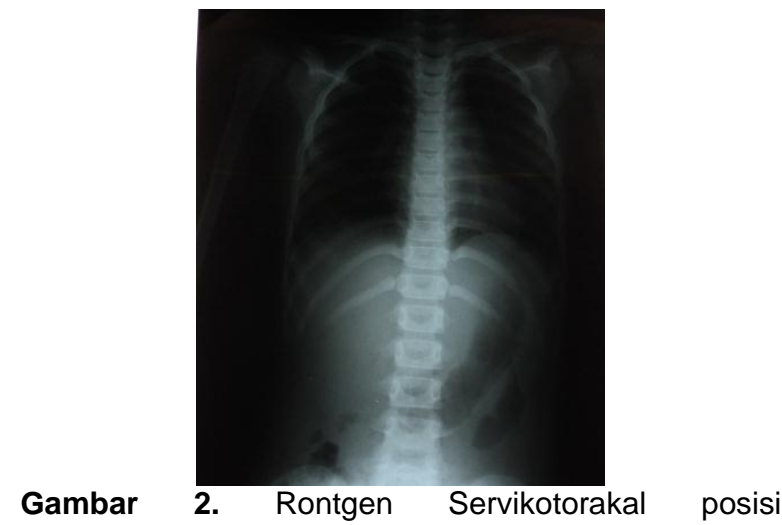
Anteroposterior (AP)

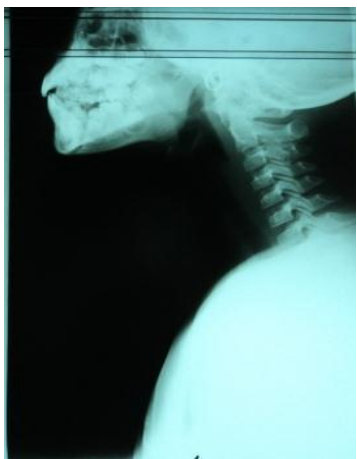

Gambar 3. Rontgen Servikotorakal posisi Lateral

Pasien didiagnosis dengan suspek corpus alienum peluit di bronkus kanan dan direncanakan untuk dilakukan bronkoskopi diagnostik dan terapeutik. Konsul ke bagian anak untuk toleransi operasi dan konsul ke bagian anestesi untuk tindakan pembiusan.
Pasien diberikan terapi sebelum operasi yaitu injeksi sefotaksim 2x500mg iv dan injeksi deksametason 10 $\mathrm{mg}$ (bolus) dan dilanjutkan dengan dosis pemeliharaan $3 \times 3 \mathrm{mg}$ (iv). Hasil konsul ke bagian anak yaitu tidak ada kelainan di bagian anak dan setuju rawat bersama di bagian anak setelah tindakan bronkoskopi.

Pada tanggal 7 Oktober 2011 dilakukan bronkoskopi diagnostik dan terapeutik dalam narkosis umum. Pasien tidur terlentang di meja operasi dan dilakukan septik antiseptik dilapangan operasi. Laringoskop removable slide dipegang dengan tangan kiri dan posisi kepala ekstensi, kemudian dimasukkan laringoskop ke dalam mulut pasien, menyusuri tepi kanan lidah, uvula sampai terlihat epiglotis dan pita suara. Bronkoskop pediatrik berukuran $4 \mathrm{~cm}$ dipegang dengan tangan kanan dan dimasukkan melalui laringoskop kemudian bronkoskop masuk melalui laring ke trakea. Slide dari laringoskop dilepas sehingga hanya bronkoskop yang tertinggal. Bronkoskop dipegang dengan tangan kiri sambil menyusuri dinding trakea, karina, muara bronkus kanan, tampak peluit bewarna merah dan dilakukan ekstraksi dengan forsep aligator kemudian dilakukan penarikan peluit bersamaan dengan bronkoskop, pada saat sampai di epiglotis peluit terjatuh dan hilang. Dilakukan evaluasi ulang dengan bronkoskop ke dalam bronkus kanan dan kiri, tidak ditemukan peluit, ekskoriasi, laserasi, dan darah mengalir. Pada saat saturasi tidak stabil dilakukan intubasi oleh dokter anestesi, kemudian dilakukan evaluasi ke orofaring dan nasofaring dengan scope hidung $0^{\circ}$ kemudian tampak peluit pada nasofaring kanan. Kemudian dilakukan ekstraksi peluit dengan pilar tonsil sampai ke orofaring dan dilanjutkan dengan forsep magil. Dilakukan evaluasi perdarahan dan operasi selesai.

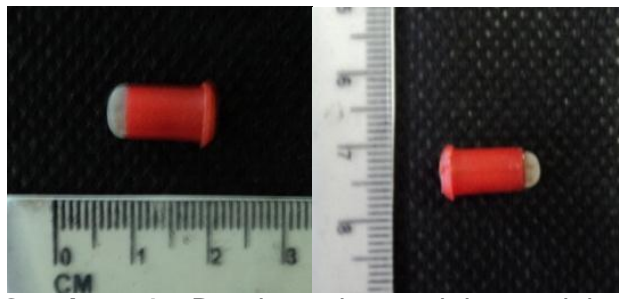

Gambar 4. Benda asing peluit setelah dilakukan bronkoskopi

Setelah tindakan pasien didiagnosis dengan post bronkoskopi diagnostik dan ekstraksi peluit di bronkus kanan. Pasien dirawat di bangsal anak dan diberikan terapi injeksi sefotaksim 2x500mg (iv), injeksi deksametason $3 \times 3 \mathrm{mg}$ (iv), injeksi ranitidin 2x20mg (iv) dan diberikan IVFD KaEn1B 14 tetes/menit (tetesan makro), diet makanan lunak jika bising usus positif.

Pada tanggal 8 Oktober 2011 (hari 1 setelah operasi) pasien tidak ada demam, batuk dan sesak nafas, pasien sudah bisa makan biasa. Pemeriksaan fisik status generalis dalam keadaan normal, pemeriksaan paru dalam batas normal dan status lokalis THT-KL dalam batas normal dan terapi dilanjutkan. Pada tanggal 10 Oktober 2011 pasien pulang paksa atas permintaan sendiri, status generalis dan lokalis THT-KL dalam batas normal. Pasien diberikan terapi sirup sefiksim $2 \times 100 \mathrm{mg}$ dan sirup ibuprofen $3 \times 100 \mathrm{mg}$. Pada tanggal 17 Oktober 2011 pasien kontrol ke poli THT-KL. Pasien tidak ada demam, batuk, sesak nafas dan nyeri dada pada pemeriksaan fisik dalam batas normal dan diberikan 
terapi sirup sefiksim 2x100mg dan sirup ibuprofen kapan perlu.

\section{Kasus 2}

Seorang anak laki-laki usia 5 tahun datang berobat ke Instalasi Gawat Darurat (IGD) RSUP Dr. M. Djamil Padang pada tanggal 4 November 2011 dengan keluhan tersedak peluit sejak 2 jam sebelum masuk rumah sakit. Sebelumnya pasien sedang bermain sambil meniup peluit, tiba-tiba pasien tersedak. Pasien batuk dan sesak nafas setelah kejadian dan setiap pasien menghirup nafas terdengar suara seperti tiupan peluit. Tidak ada suara serak dan kebiruan pada bibir dan jari. Tidak ada mual dan muntah serta air liur tergenang di mulut. Pasien masih bisa makan dan minum seperti biasa. Tidak ada riwayat nyeri menelan, hidung tersumbat serta keluar cairan di telinga.

Pada pemeriksaan fisik status generalis keadaan umum sedang, kesadaran composmentis kooperatif, nadi 104 kali / menit, nafas 36 kali / menit, suhu $37^{\circ} \mathrm{C}$, berat badan $14 \mathrm{~kg}$. Pada pemeriksaan regio toraks pada inspeksi ditemukan retraksi suprasternal, tidak ditemukan retraksi interkostal dan epigastrium, toraks kiri sama dengan kanan, palpasi fremitus kiri sama dengan kanan, perkusi sonor, pada pemeriksaan auskultasi paru suara nafas vesikuler, suara paru kanan sama dengan paru kiri, terdapat stridor, tidak terdapat ronki dan wheezing. Jantung dalam batas normal.

Pada pemeriksaan status lokalis THT-KL, telinga, hidung dan tenggorok dalam batas normal. Pada pemeriksaan laringoskopi tidak langsung dalam batas normal dan tidak ditemukan peluit.

Hasil laboratorium darah didapatkan hemoglobin $(\mathrm{Hb}) 12,3 \mathrm{~g} / \mathrm{dl}$, leukosit $7.600 / \mathrm{mm}^{3}$, hematokrit $35,1 \%$, trombosit $146.000 / \mathrm{mm}^{3}$, APTT 33,6 detik, PT 12,4 detik, Natrium (Na) $142 \mathrm{mmol} / \mathrm{L}$, Klorida (Cl) $111 \mathrm{mmol} / \mathrm{L}$, Kalium (K) $4,0 \mathrm{mmol} / \mathrm{L}$ dan gula darah sewaktu (GDS) $104 \mathrm{mg} / \mathrm{dl}$.

Pada tanggal 4 November 2011 dilakukan pemeriksaan rontgen servikotorakal posisi anteroposterior (AP) dan servikotorakal posisi lateral soft tissue setting, dan didapatkan hasil tidak tampak benda asing di saluran nafas (Gambar 5,6)

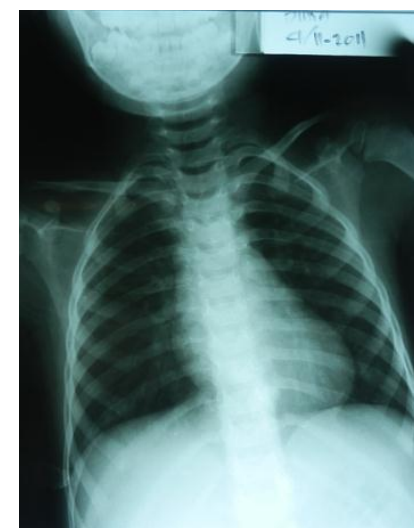

Gambar 5. Rontgen Servikotorakal posisi Anteroposterior (AP)

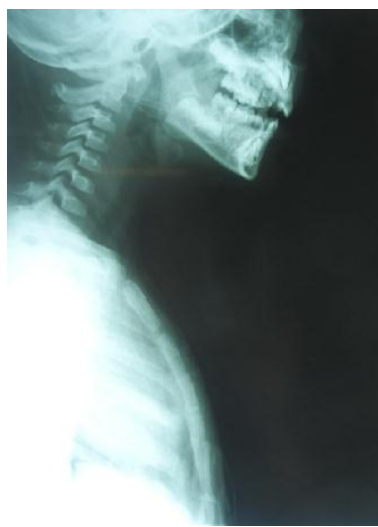

Gambar 6. Rontgen Servikotorakal posisi Lateral

Pasien didiagnosis dengan suspek corpus alienum peluit di trakea dan direncanakan dilakukan bronkoskopi diagnostik dan terapeutik. Dilakukan konsul ke bagian anak untuk toleransi operasi dan konsul ke bagian anestesi untuk tindakan pembiusan. Pasien diberikan terapi sebelum operasi yaitu injeksi seftriakson $1 \times 700 \mathrm{mg}$ iv dan injeksi deksametason 5 mg (bolus). Hasil konsul ke bagian anak yaitu tidak ada kelainan di bagian anak dan setuju rawat bersama di bagian anak setelah tindakan bronkoskopi.

Pada tanggal 4 November 2011 dilakukan bronkoskopi diagnostik dan terapeutik dalam narkosis umum. Pasien tidur terlentang di meja operasi dan dilakukan septik antiseptik dilapangan operasi. Laringoskop removable slide dipegang dengan tangan kiri dan posisi kepala ekstensi, kemudian dimasukkan laringoskop kedalam mulut pasien, menyusuri tepi kanan lidah, uvula sampai terlihat epiglotis dan pita suara. Bronkoskop pediatrik ukuran $4 \mathrm{~cm}$ dipegang dengan tangan kanan dan dimasukkan melalui laringoskop kemudian bronkoskop masuk melalui laring ke trakea. Slide dari laringoskop dilepas sehingga hanya bronkoskop yang tertinggal. Bronkoskop dipegang dengan tangan kiri sambil menyusuri dinding trakea dan karina, tampak peluit bewarna merah dan dilakukan ekstraksi dengan forsep aligator kemudian dilakukan penarikan peluit bersamaan dengan bronkoskop, pada saat sampai di epiglotis peluit terjatuh dan hilang. Dilakukan evaluasi ulang dengan bronkoskop ke dalam bronkus kanan dan kiri, tidak ditemukan peluit, ekskoriasi, laserasi, dan darah mengalir. Kemudian dilakukan evaluasi ke orofaring dan nasofaring dengan scope hidung $0^{0}$ kemudian tampak peluit pada nasofaring kiri. Kemudian dilakukan ekstraksi peluit dengan pilar tonsil sampai ke orofaring dan dilanjutkan dengan forsep magil. Dilakukan evaluasi perdarahan dan operasi selesai.

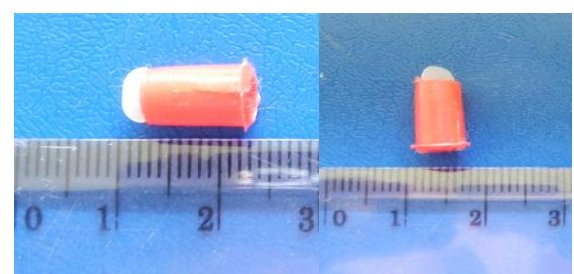

Gambar 7. Benda asing peluit setelah dilakukan bronkoskopi 
Setelah tindakan pasien didiagnosis dengan post bronkoskopi diagnostik dan ekstraksi peluit di trakea. Pasien dirawat di bangsal anak dan diberikan terapi injeksi seftriakson $1 \times 700 \mathrm{mg}$ (iv), injeksi deksametason $3 \times 2 \mathrm{mg}$ (iv), injeksi ranitidin $2 \times 14 \mathrm{mg}$ (iv), sirup erdostein 2x175mg, IVFD KaEn1B 4 tetes/menit (tetesan makro), diet makanan lunak (jika bising usus positif).

Pada tanggal 05 November 2011(hari 1 setelah operasi) pasien tidak ada demam, batuk dan sesak nafas, pasien sudah bisa makan biasa. Pemeriksaan fisik status generalis dalam keadaan normal, pemeriksaan paru dalam batas normal dan status lokalis THT-KL dalam batas normal dan terapi dilanjutkan. Pada tanggal 06 November 2011 pasien pulang paksa atas permintaan sendiri, status generalis dan lokalis dalam batas normal. Pasien diberikan terapi sirup sefiksim $2 \times 70 \mathrm{mg}$ dan ibuprofen sirup $3 \times 70 \mathrm{mg}$ Pasien tidak pernah kontrol lagi ke poli THT$\mathrm{KL}$.

\section{Kasus 3}

Seorang anak laki-laki usia 7 tahun datang berobat ke Instalasi Gawat Darurat (IGD) RSUP Dr. M. Djamil Padang pada tanggal 10 November 2011 dengan keluhan tersedak peluit sejak 15 hari sebelum masuk rumah sakit. Sebelumnya pasien sedang bermain sambil meniup peluit, tiba-tiba pasien tersedak. Pasien batuk dan sesak nafas setelah kejadian. Tidak ada suara serak dan kebiruan pada bibir dan jari. Tidak ada mual dan muntah serta air liur tergenang di mulut. Pasien masih bisa makan dan minum seperti biasa. Riwayat tidak ada nyeri menelan, hidung tersumbat serta keluar cairan di telinga.

Pada pemeriksaan fisik status generalis keadaan umum sedang, kesadaran composmentis kooperatif, nadi $90 \mathrm{kali} / \mathrm{menit}$, nafas $20 \mathrm{kali} / \mathrm{menit}$, suhu $36,8^{\circ} \mathrm{C}$, berat badan $20 \mathrm{~kg}$, Pada pemeriksaan regio toraks inspeksi tidak ditemukan retraksi suprasternal, retraksi interkostal dan epigastrium, toraks simetris kiri dan kanan, palpasi fremitus kiri sama dengan kanan, perkusi sonor, pada pemeriksaan auskultasi paru suara nafas vesikuler, suara paru kiri meningkat dari pada paru kanan, tidak terdapat stridor, ronki dan wheezing. Jantung dalam batas normal.

Pada pemeriksaan status lokalis THT-KL, telinga, hidung dan tenggorok dalam batas normal. Pada pemeriksaan laringoskopi tidak langsung dalam batas normal dan tidak ditemukan peluit.

Hasil laboratorium darah didapatkan hemoglobin $(\mathrm{Hb}) 12,9 \mathrm{~g} / \mathrm{dl}$, leukosit $8.400 / \mathrm{mm}^{3}$, hematokrit $38,7 \%$, trombosit $384.000 / \mathrm{mm}^{3}$, APTT 33,6 detik, PT 12,6 detik, Natrium (Na) $138 \mathrm{mmol} / \mathrm{L}$, Klorida (Cl) $107 \mathrm{mmol} / \mathrm{L}$, Kalium (K) 4,0 mmol/L dan gula darah sewaktu (GDS) $103 \mathrm{mg} / \mathrm{dl}$.

Pada tanggal 10 November 2011 dilakukan pemeriksaan rontgen servikotorakal posisi anteroposterior (AP) dan servikotorakal posisi lateral soft tissue setting, dan didapatkan hasil tidak tampak benda asing di saluran nafas (Gambar 8,9)

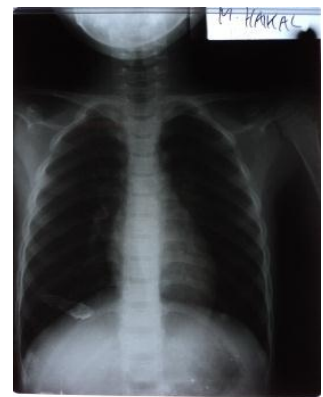

Gambar 8. Rontgen Servikotorakal posisi Anteroposterior (AP)

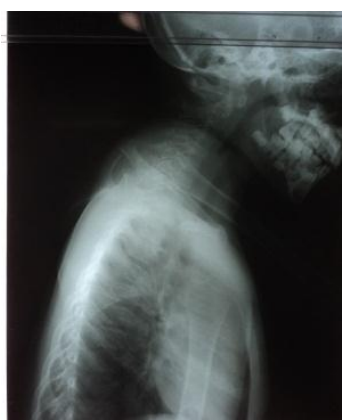

Gambar 9. Rontgen Servikotorakal posisi Lateral

Pasien didiagnosis dengan suspek corpus alienum peluit di bronkus kiri dan direncanakan dilakukan bronkoskopi diagnostik dan terapeutik. Dilakukan konsul ke bagian anak untuk toleransi operasi dan konsul ke bagian anastesi untuk tindakan pembiusan. Pasien diberikan terapi sebelum operasi yaitu injeksi seftriakson $1 \times 1 \mathrm{~g}$ iv dan injeksi deksametason $10 \mathrm{mg}$ (bolus). Hasil konsul ke bagian anak yaitu tidak ada kelainan di bagian anak dan setuju rawat bersama di bagian anak setelah tindakan bronkoskopi.

Pada tanggal 11 November 2011 dilakukan bronkoskopi diagnostik dan terapeutik dalam narkose umum. Pasien tidur terlentang di meja operasi dan dilakukan septik antiseptik dilapangan operasi. Laringoskop removable slide dipegang dengan tangan kiri dan posisi kepala ekstensi, kemudian dimasukkan laringoskop kedalam mulut pasien, menyusuri tepi kanan lidah, uvula, sampai terlihat epiglotis dan pita suara. Bronkoskop pediatrik ukuran $4 \mathrm{~cm}$ dipegang dengan tangan kanan dan dimasukkan melalui laringoskop kemudian bronkoskop masuk melalui laring ke trakea. Slide dari laringoskop dilepas sehingga hanya bronkoskop yang tertinggal. Bronkoskop dipegang dengan tangan kiri sambil menyusuri dinding trakea, karina, bronkus kanan. Pada saat masuk bronkus kiri tampak peluit bewarna merah yang sudah diselubungi oleh jaringan granulasi. Kemudian dilakukan ekstraksi dengan forsep aligator dan dilakukan penarikan peluit bersamaan dengan bronkoskop. Kemudian dilakukan evaluasi ulang dengan bronkoskop ke dalam bronkus kanan dan kiri, tidak terdapat ekskoriasi, laserasi, dan darah mengalir. Dilakukan evaluasi perdarahan dan operasi selesai. 


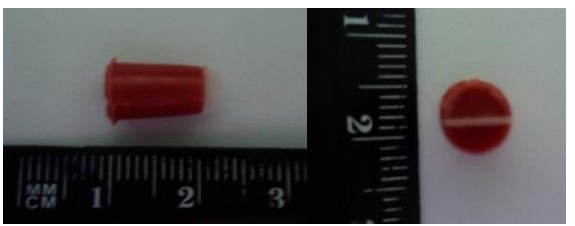

Gambar 10. Benda asing peluit setelah dilakukan bronkoskopi

Setelah operasi pasien didiagnosis dengan post bronkoskopi diagnostik dan ekstraksi peluit di bronkus kiri. Pasien dirawat di bangsal anak dan diberikan terapi injeksi seftriakson $1 \times 1 \mathrm{~g}$ (iv), injeksi deksametason $3 \times 3 \mathrm{mg}$ (iv), injeksi ranitidin 2x20mg, IVFD KaEN1B 12 tetes/menit (tetesan makro), diet makanan lunak (jika bising usus positif).

Pada tanggal 12 November 2011 (hari 1 setelah operasi) pasien tidak ada demam, batuk dan sesak nafas, pasien sudah bisa makan biasa. Pemeriksaan fisik status generalis dalam keadaan normal, pemeriksaaan paru dan status lokalis THT-KL dalam batas normal dan terapi dilanjutkan. Pada tanggal 13 November 2011 pasien pulang paksa atas permintaan sendiri, status generalis dan lokalis dalam batas normal. Pasien diberikan terapi sirup sefiksim $2 \times 100 \mathrm{mg}$ dan sirup ibuprofen $3 \times 100 \mathrm{mg}$. Pada tanggal 21 November 2011 pasien kontrol ke poli THT-KL. Pasien tidak ada demam, batuk, sesak nafas dan nyeri dada pada pemeriksaan fisik dalam batas normal dan diberikan terapi sirup sefiksim 2x100mg dan sirup ibuprofen kapan perlu.

\section{DISKUSI}

Aspirasi benda asing dapat menyebabkan meningkatnya angka morbiditas dan mortalitas pada anak. Kejadian benda asing ini terjadi pada anak di bawah umur 16 tahun dan frekuensi yang lebih sering pada anak umur 1-3 tahun. ${ }^{10,11} \mathrm{Hal}$ ini disebabkan oleh pertumbuhan gigi yang belum optimal dan belum sempurnanya koordinasi fungsi menelan. Pada ketiga kasus ini terjadi aspirasi benda asing pada umur 5 tahun dan 7 tahun. Hal ini terdapat sedikit perbedaan dari frekuensi umur yang paling sering. Berdasarkan literatur laki-laki lebih sering mengalami aspirasi benda asing dari perempuan dengan rasio $2: 1.5,10$

Berbagai faktor resiko yang mencetuskan terjadinya aspirasi benda asing yaitu belum lengkapnya pertumbuhan gigi pada anak, belum matangnya mekanisme menelan,terburu-buru saat makan dan minum,bermain saat makan, berbicara saat makanan berada di dalam mulut, susah menggenggam benda yang kecil, anak yang lebih tua suka memasukkan benda ke dalam mulut adiknya dan kurang hati-hati saat bermain. ${ }^{8,12,13}$ Pada ketiga kasus di atas faktor resiko yang menyebabkan aspirasi benda asing karena kurang hati-hati pasien saat bermain.

Lokasi aspirasi benda asing sering pada bronkus kanan (70\%), trakea (17\%) dan bronkus kiri $(13 \%)^{5,14-16} \mathrm{Hal}$ ini dikarenakan lumen bronkus kanan lebih luas dan sudut antara bronkus kanan dari lateral ke garis tengah lebih landai dibandingkan bronkus kiri. ${ }^{8} \mathrm{Hal}$ ini sesuai dengan literatur dimana pada kasus 1 terdapat benda asing pada bronkus utama kanan, kasus 2 terdapat peluit pada trakea dan kasus 3 terdapat peluit pada bronkus kiri.

Manifestasi klinik dari aspirasi benda asing dibagi menjadi 3 fase yaitu: (1) fase awal dimana gejala yang timbul langsung setelah teraspirasi benda asing. Gejala berupa batuk, terengah-engah, tersedak, rasa tercekik, stridor, wheezing (suara mengi) dan episode sianosis. (2) fase asimptomatik dimana terjadi beberapa menit dan bulan tergantung dari lokasi benda asing, derajat obstruksi jalan nafas dan reaksi inflamasi akibat materi dari benda asing. Pada fase ini benda asing mudah untuk berpindah tempat dan diikuti dengan perubahan gajala dan tanda namun dapat juga tidak mempelihatkan gejala. (3) fase komplikasi dimana gejala timbul kembali seperti batuk, sesak nafas, sputum, demam, wheezing, hemoptisis dan disertai dengan komplikasi. ${ }^{6,12}$ Pada kasus 1 dan 2 terdapat gejala yang khas seperti batuk, sesak nafas dan ditemukan suara seperti bersiul (whistling sign), lain halnya dengan kasus ke 3 tidak ditemukan gejala khas dari aspirasi benda asing namun pada pemeriksaan suara nafas terdapat perbedaan antara paru kanan dan kiri.

Tiga elemen penting dalam menegakkan diagnosis pada anak yang dicurigai adanya aspirasi benda asing yaitu anamnesis, pemeriksaan fisik dan radiografi. Anamnesis adalah kunci dasar dalam diagnosis, dari beberapa literatur keluhan tersering adalah batuk dan tersedak. 5,12,14,17 Pada obstruksi sebagian terdapat gejala wheezing pada saat auskultasi dan terdapat juga gejala dan tanda yang tidak khas seperti demam yang tidak jelas sebabnya, nyeri dada, hemoptisis dan pneumoni. ${ }^{5}$ Pada ketiga kasus ini terdapat riwayat batuk.

Benda asing organik yang paling sering adalah kacang sementara peluit adalah benda asing anorganik yang paling sering teraspirasi pada anak karena peluit sering dikemas bersamaan dengan permen sebagai promosi produk perusahaan. ${ }^{3,5}$ Pada ketiga kasus peluit diperoleh dari suatu jenis mainan.

Radiografi memiliki nilai informasi yang tinggi untuk tindakan sebelum endoskopi. Gambaran radiografi bergantung pada ukuran, lokasi, durasi dan jenis dari benda asing. Rontgen toraks dapat memperlihatkan gambaran seperti udara terperangkap (air trapping), ateletaksis, konsolidasi dan aerasi yang meningkat pada kedua lapangan paru. Pada benda asing yang terletak di daerah laring dan trakea, rontgen servikal lateral dapat memberikan informasi. ${ }^{12,15,18}$ Menurut Esclamado dan Richardson yang dikutip dari Cecille $\mathrm{dkk}^{12}$ mengatakan bahwa rontgen servikal lateral lebih banyak memperlihatkan gambaran abnormal dari pada rontgen toraks pada kasus aspirasi benda asing di laring dan trakea. ${ }^{12}$ Rontgen toraks sebaiknya dilakukan dengan posisi anteroposterior, lateral dan gambaran akhir insipirasi dan akhir ekspirasi. Rontgen dekubitus dan fluoroskopi digunakan sebagai tambahan informasi. Dari beberapa literatur lebih dari $60 \%$ hasil radiografi terdapat kelainan pada pasien dengan aspirasi benda asing dan $18 \%-60 \%$ memberikan hasil normal. ${ }^{7,12,18}$ Pada ketiga kasus telah dilakukan pemeriksaan radiografi namun memberikan hasil yang normal.

Penatalaksanaan aspirasi benda asing dengan obstruksi jalan nafas total pada anak di atas 1 tahun dapat dilakukan Heimlich maneuver. Pada bayi di bawah 1 tahun dapat dilakukan chest thrust dan back blows yaitu memukul pungggung bayi dengan posisi kepala ke arah bawah. ${ }^{10,12}$ Bronkoskopi dapat dilakukan untuk prosedur diagnostik, hal ini dilakukan karena diagnosis aspirasi benda asing tidak begitu jelas. ${ }^{7,12,10}$ Pada saat anamnesis, pemeriksaan fisik dan pemeriksaan radiografi lebih mendukung ke arah aspirasi benda asing maka bronkoskopi kaku 
merupakan pilihan awal. Bronkoskopi fleksibel tidak dipilih untuk ekstraksi benda asing di bronkus karena terbatasnya daya hisap, kurangnya kemampuan ventilasi, terbatasnya instrumen, dan kurangnya kontrol jalan nafas. Bronkoskopi fleksibel dapat di gunakan pada kasus benda asing yang terletak jauh ke arah perifer dari saluran nafas yang tidak dapat dilihat oleh bronkoskopi kaku. ${ }^{12}$ Indikasi bronkoskopi kaku dapat berupa indikasi diagnostik yaitu biopsi, dokumentasi dan bronkoskopi anak sedangkan pendekatan terapeutik yaitu hemoptisis masif, dilatasi stenosis, terapi laser, pemasangan stent, ekstraksi benda asing, reseksi tumor, krioterapi dan elektrokauter. $^{4}$ Pada ketiga kasus dilakukan bronkoskopi diagnostik dan terapeutik walaupun dari rontgen servikotorakal tidak tampak benda asing peluit namun dari anamnesis dan gejala klinis terdapat kecurigaan kearah aspirasi benda asing peluit.

Bronkoskopi segera biasanya dilakukan pada pasien yang mengalami distres pernapasan yang berat. ${ }^{1}$ Pada kasus benda asing di bronkus tidak perlu dilakukan bronkoskopi segera, sehingga kita masih memiliki waktu untuk mempersiapkan pasien dan alat dengan sebaik-baiknya. ${ }^{8}$ Pada pasien dengan benda asing di bronkus yang lebih dari 24 jam dapat dilakukan rehidrasi (infus) dan mengobati demam yang disebabkan infeksi sekunder dengan pemberian antibiotik sehingga dalam pengambilan benda asing dapat lebih aman dan lebih mungkin berhasil. Bronkoskopi ulang dilakukan jika pada bronkoskopi pertama tidak berhasil karena terdapat reaksi granulomatosa yang terlihat saat ekstraksi benda asing atau adanya pneumoni persisten. ${ }^{1}$ Pada kasus ketiga terdapat jaringan granulasi saat ekstraksi. Jaringan granulasi dapat diangkat dan ekstraksi berhasil.

Komplikasi bronkoskopi dapat berupa adanya obstruksi jalan nafas akut, laserasi di laring, pneumomediastinum, stenosis bronkial, pneumothoraks, fistel trakeoesofagus, hemoptisis masif, bronkiektasi pada daerah distal, edema laring, pneumoni, abses paru, kerusakan parenkim paru. ${ }^{92}$ Pemberian terapi kortikosteroid dan antibiotik sebelum tindakan bronkoskopi masih terdapatnya perbedaan pendapat. Menurut Charles $\mathrm{H} \mathrm{dkk}^{4}$ kortikosteroid jangka pendek dapat diberikan pada pasien sebelum tindakan ekstraksi benda asing, hal ini bertujuan untuk mengurangi edema subglotik dan mengurangi inflamasi pada benda asing yang terbungkus oleh darah dan jaringan granulasi. Pemberian kortikosteroid setelah operasi dapat diberikan pada pasien yang mengalami edema subglotik dan pasien yang akan dilakukan bronkoskopi ulang., ${ }^{1,4}$ Antibiotik sebelum tindakan diberikan pada pasien yang secara klinis dan radiografi terdapat tanda-tanda infeksi. ${ }^{12}$ Pemberian antibiotik dan pemeriksaan rontgen toraks setelah tindakan bronkoskopi tidak rutin dilakukan. ${ }^{12}$ Pada ketiga kasus di atas diberikan terapi antibiotik untuk menghindari terjadinya infeksi. Pada kasus yang ketiga sangat diperlukan antibiotik, kortikosteroid dan rontgen toraks untuk menghindari terjadinya infeksi dan untuk menilai apakah ada komplikasi setelah tindakan akibat jaringan granulasi.

\section{DAFTAR PUSTAKA}

1. Yadav et al. Airway foreign bodies in children: experience of 132 cases. Singapore Med J. 2007; 48 (9) : 850-3.

2. Nader $S$ et al. Foreign body aspirations in Infancy: a 20-year experience. Int J Med Sci. 2009; 6 (6):332-8.

3. Muhammad A et al. Analysis of tracheobronchial foreign bodies with respect to sex, age, type and presentation. J Ayub Med Coll Abbottabad. 2007; 19(1):13-5.

4. Charles $\mathrm{H}$, Alain M. Foreign Body Removal in Adults and Children in Interventional Bronchoscopy Vol 30. Cape Town: Karger; 2000. pp 96-107.

5. Muhammad T et al. Rigid bronchoscopy; a case series of 62 cases in $\mathrm{CMH}$ rawalpindi. Proffesional Med J. 2011;18(3): 402-6.

6. Alan DM et al. Foreign bodies of the airway. Available http://emedicine.medscape.com/article/87498 overview\#showall Cited on August 2011

7. Arbay $\mathrm{O}$ et al. Bronchoscopy for evaluation of foreign body aspiration in children. $J$ Pediatr Surg. 2003; 38(8):1170-6.

8. Ballenger JJ. Bronkologi. Dalam Penyakit telinga hidung tenggorrok kepala\& leher. Edisi 13. Jakarta: Binarupa aksara; 1997.p619-643.

9. Rani K, Arthur S, Armin E. Airway Anatomy for The Bronchoscopist in Introduction Bronchoscopy. United States: Cambridge; 2008. pp 39.

10. Martin E W. Foreign body aspiration clinical presentation. Available from http://emedicine.medscape.com/article/298940overview Cited on Jun 2010

11. Bist S S. Neglected bronchial foreign body in an adult. JK science. 2006;8(4):222-224.

12. Cecille $G S$ et al. Foreign body aspiration in Respiratory Insults and Intensive Care. United States: 2001. pp 331-5

13. Aydogan LB et al. Rigid boncoscopy for the suspicion of foreign body in airway. Int $\mathrm{J}$ Pediatr Otorhinolaryngology. 2006;70:823-8.

14. Abdulmajid $\mathrm{O} A$ et al. Aspirated foreign bodies in the tracheobronchial tree: report of 250 cases. Thorax. 1976;31:635-40.

15. Zerella et al. Foreign body aspiration in children: value of radiography and complications of bronchoscopy. J Pediatr surg. 1998; 33(11): 1651-4.

16. Arif raza K, Noor sahib K. Management of whistle as a foreign body tracheobronchial tree. JPMI.1998;18(4):602-6.

17. Shafkat A L, Lateef M. Foreign body in tracheobronchial tree. JK Science. 2004;6(2):7780.

18. Haliloghu $M$ et al. European journal of radiology. 2003;48:188-92. 